\title{
Existing feeding practices and production performance of lactating buffaloes in selected agro-climatic zones of Bangladesh
}

\author{
SMR Rahman ${ }^{1}$, MN Islam ${ }^{1} *$, MH Rashid ${ }^{1}$, NR Sarker ${ }^{2}$, MSR Siddiki $^{1}$, MS Bari $^{1}$ and MA Islam ${ }^{1}$ \\ ${ }^{1}$ Department of Dairy Science, Faculty of Animal Husbandry, Bangladesh Agricultural University, Mymensingh,
} 2202; ${ }^{2}$ Bangladesh Livestock Research Institute, Savar, Dhaka

\begin{abstract}
A study was conducted to observe the existing feeding practices, nutritional supply and production performance of the lactating buffaloes in some selected agro-climatic zones of Bangladesh, viz. Bhola (AEZ-18, Coastal area), Mymensingh (AEZ-22, River basin area) and Dinajpur (AEZ-27, Drought area). Data on availability, amount and types of feeds and fodders fed to the lactating buffaloes, body weight, milk yield and quality and lactation length were collected from 30 farmers of the each selected locations. In this investigation, the mostly used feed ingredients found were rice straw, locally available green grasses, wheat bran, broken maize, mustard oil cake and broken rice. Total feed supply (DM kg/h/d) to lactating buffaloes were 17.4, 14.5 and 13.0 in coastal, river basin and drought areas, respectively, $(p>0.05)$. But significantly $(p=0.000)$ different amount $(D M \mathrm{~kg} / \mathrm{h} / \mathrm{d})$ of concentrate were supplied in coastal (1.5), river basin (1.8) and drought (2.7) areas. The highest amount $(\mathrm{kg} / \mathrm{h} / \mathrm{d})$ of green grass was supplied in coastal area (5.0) followed by river basin area (4.3) and drought area (1.3). Accordingly, amount $(\mathrm{kg} / \mathrm{d})$ of DCP and TDN were supplied was higher in coastal area ( 0.365 and 6.417 , respectively) than that of the river basin and drought areas $(0.247-$ 0.248 and 5.501-5.891, respectively), which were below their requirements. Significantly $(p=0.000)$ larger lactating buffaloes were found in the river basin and drought areas (weighed $372-380 \mathrm{~kg} / \mathrm{h}$ ) than that of coastal area $(242 \mathrm{~kg} / \mathrm{h}$ ). The average daily milk yield was found significantly highest $(p=0.000)$ in the drought area $(5.3 \mathrm{~L} / \mathrm{d})$ which was $1.4 \mathrm{~L}$ and $3.1 \mathrm{~L}$ more than that of the river basin and coastal area, respectively. The $4 \%$ FCM yield was found two times more $(p=0.000)$ in drought area $(7.7 \mathrm{~kg} / \mathrm{d})$ than that of the coastal $(3.1 \mathrm{~kg} / \mathrm{d})$ and river basin $(3.6 \mathrm{~kg} / \mathrm{d})$ area. On the other hand, the significantly $(p=0.000)$ highest lactation length and lactation yield were $294 \mathrm{~d}$ and $1085 \mathrm{~L}$, in the river basin area, which were $189 \mathrm{~d}$ and $1007 \mathrm{~L}$ in drought area and 197d and $429 \mathrm{~L}$ in coastal area, respectively. Among the milk constituents, protein, ash and lactose content was found higher in drought area than that of the other two areas $(p=0.001)$. In conclusion, the prevailing variations are evidently considerable. Therefore, suggesting further works for large scale baseline data regarding buffalo populations, nutritive quality of feeds and fodder, effectiveness of existing management tools and adoption of new technologies.
\end{abstract}

Key words: feeding practices, nutritional status, milk production, lactating buffaloes, climatic zone

Bangladesh Animal Husbandry Association. All rights reserved. Bang. J. Anim. Sci. 2019. 48 (2):127-138

\section{Introduction}

The world buffalo population is estimated to be approximately 195 million spread in 42 countries, of which 180 million (92.52\%) are in Asia and the rest are in other parts of the world (FAO,2012). Bangladesh has only $0.72 \%$ buffaloes of total world population (FAO, 2012) and very thinly $3.77 / \mathrm{Km}^{2}$ (0.39 to $\left.15.4 / \mathrm{Km} 2\right)$ distributed (Huque and Khan 2017). The number of buffalo in proportion to the human population $(\mathrm{B}: 103 \mathrm{H})$ in Bangladesh were $10.1-32 / 10^{3}$ in coastal areas (south delta), $5.1-10 / 10^{3}$ in drought area (the north the west districts) and rest of the districts (river basin) holding $0.3-5.0 / 10^{3}$ (Huque and Khan 2017). Bangladesh has thirty agroclimatic zone (AEZ) which represent different land form, depth and duration of seasonal flooding, cropping pattern, temperature, humidity, day light, length and rainfall. Climatic condition of Bangladesh is nearly similar to India and has lots of river and marshy lands that is favorable for raising buffaloes (Rahman et al.,2018).

Buffalo production system varies widely in accordance with climate, soil, feed resources and socio-economic opportunities in Bangladesh (Saadullah, 2012). Buffaloes are well adapted to adverse climatic condition e.g. flood, drought, high tidal wave in coastal areas and they can

*Corresponding author: mnislamds@yahoo.com 


\section{Buffaloes in different climatic zones of Bangladesh}

thrive well under minimum or without housing facilities. Buffaloes are resistant to several tropical diseases in South Asia, while enduring divers harsh climates making it a preferred climate-resilient livestock species (Siddiky, 2018). The contribution of buffalo milk in national milk supply in India, Pakistan and Nepal is $51.2 \%, 59.5 \%$ and $66.6 \%$, respectively (FAO 2014) whereas in Bangladesh it is only $2 \%$ (Hamid, 2016). Though the trend of increase in buffalo population $(2.20 \%)$ in recent year is relatively higher than that of the cattle $(0.44 \%)$ but buffalo milk production is not contributing significantly to national production in Bangladesh (Islam, 2017), though in some parts, buffalo milk is frequently mixed with cow milk and sold as cow milk (Islam, 2014). So if we want to achieve the requirement of animal protein as SDG, Buffalo will be an important option. However, being the closest neighbor, Bangladesh has never given buffalo as prioritized milking animal despite of their important role in the national economy. Most of the buffalo farmers followed conventional feeding practices based on locally available crop residues both concentrates and roughage. Feeding of locally available feed resources would be the only way for sustainable animal production in developing countries (Devendra and Leng, 2011). Crop residues has been utilized efficiently by buffaloes as prevalence of higher rumen microbial population that produce more ammonia nitrogen in buffalo leading to higher production of microbial protein (Poondusit, 2001). In order to express full genetic potentials of milk yield, it is necessary to provide suitable and balanced nutrition. According to Jatinder et al. (2018) feeding balanced complete feed mixture with available feed ingredients could improve the milk production of buffaloes. Supplemental feeding could also improve the milk production (Siddiki, 2017). Over-feeding, under-feeding and imbalanced diets lead to nutritional and reproductive disorders of buffaloes (Chavda and Parnarker, 2016). Still now there is no recognized feeding system in Bangladesh. Farmer provides daily ration without considering production, especially daily milk yield and fat content in milk. They have neither scientific knowledge nor following any feeding system to satisfy the nutrient requirements of the buffaloes. As a result, under/over nutrition is a great threat to express the productive and reproductive potentialities of buffaloes. Moreover, there were few scientific attempts to evaluate the existing production status in relation to feed availability and nutrient requirement of lactating buffaloes in Bangladesh. Hence, the present investigation was undertaken to assess the existing feed supply and production performance of lactating buffaloes that could contribute in preparing a nutritional plan for increased buffalo milk production with locally available feed resources.

\section{Materials and Methods}

\section{Study area and selection of buffalo farmers}

A total of 30 buffalo farmers were randomly selected from each of the three different agroclimatic districts, namely-Bhola (AEZ-18, coastal area), Mymensingh (AEZ-22, river basin) and Dinajpur (AEZ-27, drought area). Bhola sadar, Trishal and Birganj sub-district have been chosen, respectively owe to the availability of the buffalo. The selected farmers have at least one lactating buffalo with calf and had the intensive or semi-intensive management system. The buffaloes at the farmers' level were of nondescriptive type.

\section{Conducting survey and sample collection}

An interview schedule and well planned questionnaire was prepared to collect data on available feed resources for buffaloes, amount of feed supplied to the buffalo, and buffalo milk production. Face-to-face interview was conducted by visiting each of the farmers. During visit, 15 individual milk samples ( $50 \mathrm{~mL} / \mathrm{sample}$ ) were also collected from each of the sub-district. The milk samples were immediately placed in a home freezer, transported in an ice box and again placed in a regular freezer in the Dairy Chemistry Laboratory, Department of Dairy Science, Bangladesh Agricultural University, Mymensingh2202, until further analyses. Milk samples were analyzed for fat, protein, lactose and ash content by auto-milk analyzer (Lactoscan, Ultrasonic Milk Analyzer; Model MIA-SLP-60, S/N-70148; MILKOTONIC Ltd., Bulgaria 6000. Stara zagora). During the survey, heart girth of the buffalo was also measured by a measuring tape (HMBR SINOU.S.A) and corresponding body weight was recorded.

\section{Determine nutrient availability and requirements}

The nutrient content of the different feed ingredients was calculated by consulting Feedipidia (2018), NRC (2001), TNAU Agritech Portal (2018) and Kearl (1982). Subsequently the nutrient supply was calculated by using feeds and fodder supply record. The DCP and TDN requirements of buffalo were worked out as per Kearl (1982). The 4\% fat-corrected milk (FCM) yield was calculated from milk yield and fat percentage data using standard formulae (Gaines, 1928). (FCM for each $\mathrm{kg}$ of milk $=0.4 \mathrm{M}+0.15 \mathrm{~F}$; 
FCM was the weight of fat corrected milk (Kg); M is the quantity of milk, $\mathrm{F}$ is fat content of milk).

Table 1: Climatic data of selected coastal, river basin and drought area of Bangladesh

\begin{tabular}{lccc}
\hline Characters & Coastal & $\begin{array}{l}\text { River } \\
\text { basin }\end{array}$ & Drought \\
\hline Climate type & $\begin{array}{l}\text { Tropical } \\
\text { wet }\end{array}$ & $\begin{array}{l}\text { Tropical } \\
\text { wet }\end{array}$ & $\begin{array}{l}\text { Tropical } \\
\text { wet and } \\
\text { dry }\end{array}$ \\
$\begin{array}{l}\text { Temperature } \\
\text { (Min-Max) }\end{array}$ & $19-29^{\circ} \mathrm{C}$ & $12-33^{\circ} \mathrm{C}$ & $5-45^{\circ} \mathrm{C}$ \\
$\begin{array}{l}\text { Humidity (\%) } \\
\text { Average yearly } \\
\text { rain fall(mm) }\end{array}$ & 71 & 76 & 79 \\
\hline
\end{tabular}

Source:https://en.wikipedia.org/wiki/

Köppen_climate_classification visited 03.02.2018 13.53PM; https://www.timeanddate.com/weather/ @1336136/climate visited 31.01/2018 17:23 PM.

\section{Statistical analysis}

Statistical analyses were carried out through SPSS version 16 computer package and analysis of variance was done by ANOVA. Duncan Multiple Range Test (DMRT) was used to determine the significant difference among the mean.

\section{Results}

\section{Feeds and fodder availability}

Available feeds and fodders fed to lactating buffaloes by the selected farmers in studied agroclimatic zone are presented in Table 2. Among the roughages, local green grass like dol (Dichanthium annulatum), durba (Cynodon dactylon), halancha (Enhydra fluctuans), sesbania (Sesbania rostrata), water hyacinth (Eichhornia crassipes) and rice (Oryza sativa) straw reveals the mostly used in all three areas. It also indicates that the farmers under this study in coastal and river basin area used diversified roughages than that of the respondents in drought area. The green roughage fed either fresh as pasture or in a cut-and-carry system. Wheat bran, broken maize, mustard oil cake, khesari (Lathyrus sativus) and broken rice were used as concentrate for feeding their buffaloes. All other ingredients had region specific responses. Most of the roughages and concentrate items were found available year round with a little fluctuation except Mash kalai (Vigna mungo) being available only in late winter.

\section{Feed supply to lactating buffalo}

Table 3 represents the average feed supply (DM $\mathrm{kg} /$ day/head) of lactating buffalo under different agro-climatic zones of Bangladesh. Farmers provided similar $(p>0.05)$ amount of feed $(13-17$
DM $\mathrm{kg} /$ day/head) to their buffaloes among the three agro-climatic zones, but highest amount of concentrate was supplied in drought area (2.72 DM $\mathrm{kg} /$ day/head) which was significantly $(p=0.000)$ higher than that of the river basin (0.9 kg more) and costal (1.2 kg more) areas. Result also indicates that concentrate supplementation was a common feeding practice of all farmers in drought and river basin areas but only $57.14 \%$ farmers supplied concentrate feed in coastal area. Farmers in river basin $(18 \%)$ and drought (57\%) area added salt (0.1-0.3 DM $\mathrm{kg} /$ day/head) in concentrate mixture but this practice is completely absent in coastal area due to salinity of water. The result revealed that availability of green grass was significantly $(p=0.000)$ lower in drought area (1.3 DM $\mathrm{kg} / \mathrm{day} / \mathrm{head}$ ) which was 3.0 and $3.7 \mathrm{~kg}$ less than that of river basin and costal area respectively. Around $17 \%$ farmers in drought area did not provide green grass to their buffalo but in case of costal and river basin area this value was 0-5\% only. Availability of green grass in coastal areas was more (range 2-11 DM kg/day/head) as there was more chare land which ensure green grass availability for buffaloes. The land of river basin area was inundated by the water for 4-6 month during flood season, it may facilitate the relatively more supply of green grass than drought areas. The range of green grass supplied was very low (0.320-4.00 DM $\mathrm{kg} /$ day/head) in drought area due to the land was occupied by several crops and vegetables throughout the year. Buffaloes of the studied areas were received around similar amount (9-11 DM $\mathrm{kg} / \mathrm{day} / \mathrm{head}$ ) of rice straw. Range of paddy straw supplied was wide in drought area, as cropping pattern was friendly for more rice production.

\section{Nutritional supply}

The average estimated levels of nutrients supplied to lactating buffaloes in different agroclimatic zone of Bangladesh are presented in Table 4. Result revealed that buffaloes of costal area got 1.5 times more DCP than that of buffaloes in river basin and drought area. Similarly buffaloes of costal area received $0.5 \mathrm{Kg}$ $(8 \%)$ and $0.9 \mathrm{Kg}(14 \%)$ more TDN than that of buffaloes of drought and river basin area, respectively. Results also indicated that around $72-87 \%$ DCP and $8-32 \%$ TDN comes from concentrates sources among the study areas. Drought buffaloes are more $(87 \%$ for DCP and $32 \%$ for TDN, respectively) dependent on concentrate than that of the buffaloes of other two areas (72-78\% for DCP and $18-25 \%$ for TDN, respectively). 
Table 2: Feeds and fodders used to fed the lactating buffaloes in selected coastal (C), river basin (RB) and drought (D) areas of Bangladesh

\begin{tabular}{|c|c|c|c|c|}
\hline Name of feed resources & C & RB & D & Time of availability \\
\hline Local green grass (non-descriptive) & + & + & + & $\begin{array}{l}\text { Year round available but more in summer } \\
\text { than winter }\end{array}$ \\
\hline Kheshari hay (Lathyrus sativus) & + & - & - & $\begin{array}{l}\text { Seasonal but more in late winter than } \\
\text { summer }\end{array}$ \\
\hline Mash kalai hay (Vigna mungo) & - & + & - & Available in late winter \\
\hline Rice straw (Oryza sativa) & + & + & + & Year round available \\
\hline Rice polish (Oryza sativa) & - & + & - & Year round available \\
\hline Broken rice (Oryza sativa) & - & + & + & Year round available \\
\hline Rice gruel (Oryza sativa) & - & - & + & Year round available \\
\hline Rice bran (Oryza sativa) & - & - & + & Year round available \\
\hline Rice husk (Oryza sativa) & + & - & - & Year round available \\
\hline Wheat bran (Triticum aestivum) & + & + & + & Year round available but more in late winter \\
\hline Broken maize (Zea mays) & + & + & + & Year round available \\
\hline Mustard oil cake (Brassica spp.) & - & + & + & Year round available but more in late winter \\
\hline Soybean meal (Glycine max) & + & - & - & Year round available \\
\hline $\begin{array}{l}\text { Ready concentrate feed (Commercial } \\
\text { mixed feed) }\end{array}$ & - & - & + & Year round available \\
\hline Crushed kheshari (Lathairus sativus) & - & - & + & $\begin{array}{l}\text { Seasonal but production is more in late winter } \\
\text { than summer }\end{array}$ \\
\hline Molasses (Saccharum officinarum L.) & - & - & + & Year round available \\
\hline
\end{tabular}

+ , used by respondents for the feeding of lactating buffaloes; - , not used by respondents for the feeding of lactating buffaloes.

Table 5 and Figure 1 clearly demonstrate that DCP and TDN were deficit in all three areas. Deficit of DCP (Kg/day) was $47 \%, 68 \%$ and $69 \%$, for coastal, drought and river basin areas, respectively as compared to Kearl, (1982). Result also indicates that costal buffaloes were deficit in $0.35 \mathrm{Kg} /$ day/head) TDN (5\%) compared to Kearl 1982 requirement and this value was 6 times and 7 times more in case of drought and river basin buffaloes, respectively (Table 5 and Figure 1).

\section{Production variables}

Production performances of lactating buffaloes in different climatic areas of Bangladesh are illustrated in Table 6 . The heaviest lactating buffaloes were found in river basin and drought area $(p>0.05)$ and the average live weight was varied from $372-380 \mathrm{~kg}$. The coastal area had the comparatively smaller lactating buffalo which was
$130-138 \mathrm{~kg}$ less than that of the other two groups $(p=0.000)$. The average daily milk production per buffalo per day among the three areas differed significantly $(p=0.000)$. The highest milk production was $5.3 \mathrm{~L}$ recorded in the drought area which was $3.1 \mathrm{~L}$ and $1.4 \mathrm{~L}$ more than that of the coastal and river basin area, respectively. The highest average lactation yield (L/lactation) was $1085 \mathrm{~L}$ (in river basin area) followed by drought and coastal area with a production of 78 and $656 \mathrm{~L}$ less than that of the river basin area, respectively $(p=0.000)$. However, the lactation length was found similar in the Coastal and Drought areas (189-197 d; $p>0.05)$. They differ significantly with the River basin area $(p=0.000)$ which was $96-104 d$ more than those two areas. 
Table 3: Average feed supply (DM kg/h/d) of lactating buffalo in selected coastal (C), river basin (RB) and drought (D) areas of Bangladesh

\begin{tabular}{|c|c|c|c|c|c|c|c|c|c|c|}
\hline \multirow[b]{2}{*}{ Items } & \multicolumn{3}{|c|}{ C } & \multicolumn{3}{|c|}{ RB } & \multicolumn{3}{|c|}{ D } & \multirow[b]{2}{*}{$\begin{array}{c}P \\
\text { value }\end{array}$} \\
\hline & Mean \pm SD & Range & $\begin{array}{l}\text { Use } \\
\% \text { in } \\
\text { farme } \\
\text { rs } \\
(n=3 \\
0)\end{array}$ & $\begin{array}{l}\text { Mean } \pm S \\
\text { D }\end{array}$ & Range & $\begin{array}{l}\text { Use \% } \\
\text { in } \\
\text { farme } \\
\text { rs } \\
(n=30 \\
)\end{array}$ & Mean \pm SD & Range & $\begin{array}{l}\text { Use \% } \\
\text { in } \\
\text { farmer } \\
\mathrm{s} \\
(\mathrm{n}=30 \\
)^{5}\end{array}$ & \\
\hline $\begin{array}{l}\text { Concentr } \\
\text { ate feed }\end{array}$ & $1.5^{\mathrm{b}} \pm 0.8$ & $0.4-2.6$ & 57.1 & $1.8^{\mathrm{b}} \pm 0.3$ & $1.8-2.6$ & 100.0 & $2.7^{\mathrm{a}} \pm 0.7$ & $0.9-4.4$ & 100.0 & 0.000 \\
\hline $\begin{array}{l}\text { Rice } \\
\text { Straw }\end{array}$ & $10.9 \pm 2.8$ & $4.5-16.0$ & 90.5 & $9.1 \pm 2.3$ & $9.0-10.8$ & 95.5 & $9.1 \pm 8.0$ & $4.5-36.0$ & 100.0 & 0.262 \\
\hline $\begin{array}{l}\text { Green } \\
\text { grass }\end{array}$ & $5.0^{\mathrm{a}} \pm 2.9$ & $1.6-11.3$ & 100.0 & $4.3^{a} \pm 0.5$ & $3.2-4.8$ & 95.0 & $1.3^{\mathrm{b}} \pm 1.0$ & $0.3-4.0$ & 83.0 & 0.000 \\
\hline $\begin{array}{l}\text { Common } \\
\text { salt }\end{array}$ & - & - & - & $0.1 \pm 0.03$ & $0.1-0.2$ & 18.2 & $0.2 \pm 0.1$ & $0.03-0.3$ & 56.7 & 0.000 \\
\hline $\begin{array}{l}\text { Total } \\
\text { supply }\end{array}$ & $17.4 \pm 3.3$ & $6.4-20.3$ & - & $14.5 \pm 3.4$ & $1.8-16.6$ & - & $13.0 \pm 8.9$ & $7.1-42.9$ & - & 0.109 \\
\hline
\end{tabular}

Table 4: Average estimated levels of nutrients supplied to lactating buffaloes in selected coastal (C), river basin (RB) and drought (D) areas of Bangladesh

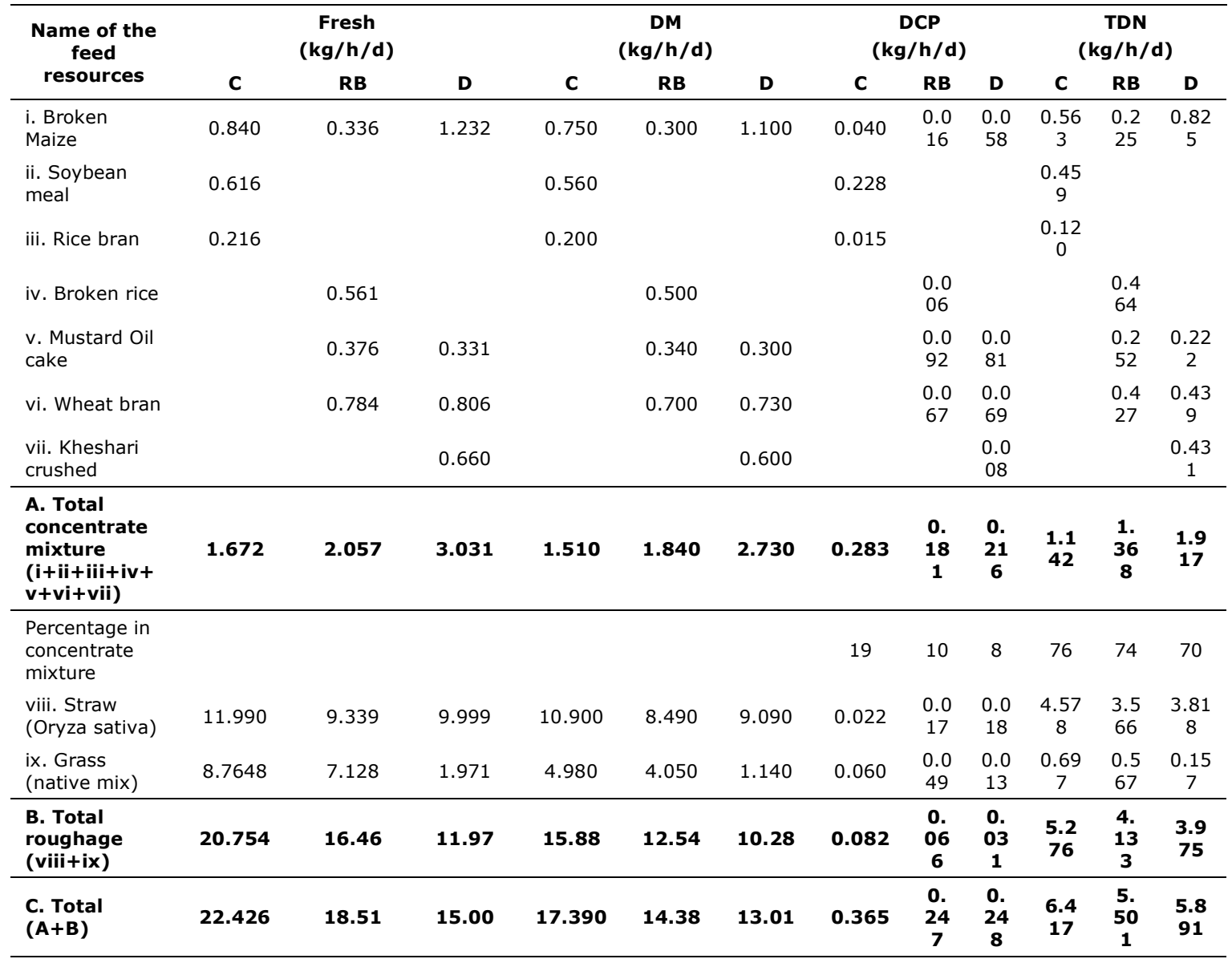

DM, DCP and TDN of feeds and fodder using value as given by Kearl (1982), Feedipidia.org (2018) and TNAU Agritech Portal (2018). 
Buffaloes in different climatic zones of Bangladesh

Table 5: Deficit (-) and surplus (+) of DCP and TDN in lactating buffaloes in selected costal (C), river basin (RB) and Drought (D) area of Bangladesh

\begin{tabular}{ccccccc}
\hline Areas & $\begin{array}{l}\text { Total } \\
\text { requirement } \\
\text { of DCP } \\
(\mathbf{g} / \mathbf{d})\end{array}$ & $\begin{array}{l}\text { Total } \\
\text { supply of } \\
\text { DCP (g/d) }\end{array}$ & $\begin{array}{l}\text { Deficit (-) } \\
\text { /surplus } \\
(+) \text { of DCP }\end{array}$ & $\begin{array}{l}\text { TDN } \\
\text { requirement } \\
(\mathbf{g} / \mathbf{d})\end{array}$ & $\begin{array}{l}\text { TDN } \\
\text { supply } \\
\text { (Kg/day) }\end{array}$ & $\begin{array}{l}\text { Deficit } \\
\text { )/surplus } \\
\text { (+) of TDN }\end{array}$ \\
\hline C & 697 & 364.790 & -332.210 & 6.770 & 6.416 & -0.353 \\
RB & 786 & 246.855 & -539.145 & 8.090 & 5.500 & -2.589 \\
D & 786 & 247.84 & -538.160 & 8.090 & 5.891 & -2.199 \\
\hline
\end{tabular}

Figure in the parenthesis indicate the percentage of nutrient deficit $(-)$ /surplus $(+)$ than requirement; Requirements for DCP and TDN were worked out according to Kearl 1982

The protein content of the milk in coastal and river basin area were found similar (3.6 - 3.7\%; $p>0.05)$ which differ significantly $(p=0.001)$ with drought area $(4.1 \%)$. Lactose percentage was varied from $4-5$ and showed highly significant difference $(p=0.000)$ among the study areas. The fat percentage of the milk from these areas showed a non-significant difference ranging from 6.6-7.8. However, drought area had the highest $4 \%$ fat corrected milk yield ( $8 \mathrm{~kg} / \mathrm{d} ; \mathrm{p}=0.000$ ) which was more than double of the $4 \%$ FCM yield of the coastal and river basin area. The ash content in milk of river basin and drought area were found similar $(0.7 ; p>0.05)$ which differ significantly from the coastal area $(p=0.000)$.

\section{Discussion}

\section{Available feed resources}

Local grass, crop residues, agro-industrial by products were potentially available for using by the buffalo farmers in our study which is mostly depends on season and soil types. Rice straw and naturally grown local green grasses were the basal feed (main roughages) for feeding buffalo and concentrate provided as supplement with roughages. The result of present study resembles with the findings of Uddin (2001), Sarker et al. (2017). Uddin (2001) found that hundred percent lactating buffaloes offered rice straw, local grass, and wheat bran in river basin area (Trishal of Mymensingh; Dhunat of Bogra) of Bangladesh. About $95 \%$ households $(\mathrm{HHs}$ ) fed rice straw and about $81 \% \mathrm{HHs}$ fed cut and carry green grass to their animals. Most of the native grasses are grown more in summer and some others like Kawn, Khesari and Maskalai are grown in winter (Sarker et al., 2017). Different species of local natural grasses e.g. durba, dol, baksha, kolmi and shama were found in all climatic zone (coastal, river basin and drought) of Bangladesh which were used as animals forages (Rahman et al., 2017). Local grass e.g. dol, durba, halancha, sesbania, water hyacinth mash kalai and kheshari kalai were fed to lactating buffaloes in different climatic areas in the present study which is similar to Rahman et al. (2017). Islam et al. (2002) identified more than fifty different types of local green grasses from different Agro Ecological Zones (AEZs) in Bangladesh which were mostly common and more potential native grasses for animals. Similar findings are found in present study. Rice straw has traditionally been used as a feedstuff in many parts of the world (Nader and Robinson, 2008; Akbar, 1992). Farmers were practiced stall feeding and sometimes they were tethered their animals to the roadsides, riverbed and fallow lands due to shortage of grassing land (Rahman et al., 1998). But in our study, animals were considered grassing for 4-5 hours in a day for coastal and river basin areas, however, stall feeding was followed in drought area. Ahmed (2006) showed that common concentrates like wheat bran, rice polish, pea bran, khesari bran, matikalai bran, lentil, sesame oil cake, coconut oil cake and mustard oil cake were available round the year for dairy animal which support our findings. The result of the present study is in accordance with Tareque (1991) and who claimed that rice straw and naturally grown local green grasses were the major contributor of roughages for feeding buffalo. Rice straw alone contributed $87 \%$ of roughage portion of the dairy feed during the rainy and winter season when green grasses are very limited.

\section{Feed supply}

Dairy buffalo productions depend on quantitative and qualitative feeds and fodder supply that influence performance of milking animal. Nahar et al. (2015) found that $22.23 \%$ farmers supplied only straw, $95.55 \%$ farmers supplied straw with roughages, and $8.89 \%$ farmers supplied only concentrate under extensive system in Bhola district. In the Ganges-Brahmaputra flood plain, dairy buffaloes were reared in a semi-intensive system in which farmer raised buffaloes with 
minimum inputs. In our study, 57\%, 90.47\%, and $100 \%$ farmers supplied concentrate mixture, straw and green grass, respectively under semiintensive system of Bhola District (coastal area). All farmer provided concentrate feed and $95 \%$ farmers provided straw and green grass in river basin areas (Table 2). The overall average DM intake of the buffaloes in Patan district of India was observed as $16.94 \mathrm{~kg} / \mathrm{d}$ which indicated that the buffaloes in the district got adequate DM as per the requirement that produced $11.18 \mathrm{~L} \mathrm{milk/d}$ (Chavda and Parnerkar, 2016). Similar observation was recorded by Bakshi and Wadhwa, (2011) in dairy animals of western plain zone of Punjab State of India. However, Vidya et al. (2013) reported that dairy animals in Sonbhadra district of Uttar Pradesh of India got less DM than the requirement. But Total feed supply to lactating buffaloes were 13-17 kg DM /day/head, in the study areas, respectively where average milk production were very $2-5 \mathrm{~L} / \mathrm{d}$. The dry matter intake (DMI kg/d) of milking buffaloes in different locations was varies from 13-15 (Siddiki, 2017) but in our study dry matter supply $(\mathrm{kg} / \mathrm{d})$ of milking buffaloes in different locations varied from 13-18 (kg/day). Similar observation (14-16 kg DM/h/d) had also be reported by Uddin, (2001). Present study for feed supply on DM basis is closely similar to feed intake of milking buffaloes studied by Siddiki, (2017) and Uddin, (2001).

\section{Nutritional supply}

Existing feeding practice of buffaloes without considering their milk production and composition negatively affects the productivity of the buffaloes as well as the farmer economy. Feeding practice deprives the potential high milk producers by providing less nutrient in terms of protein and energy and also over burdens the low producers by providing over nutrition that causes economic losses of the farmers (Habib et al., 2007). In the present study, more energy came from low quality roughages (e.g. rice straw) than concentrate mixture. On the other hand, more DCP supplied from concentrate mixture than roughage (Table 4). Daily average DCP supply in the buffaloes in Bhola, Mymensingh and Dinajpur district were $364.79,246.85$ and $247.84 \mathrm{~g} / \mathrm{d}$, respectively, which were deficit as per requirement (Table 4 ). Daily average DCP intake in the buffaloes in Patan district of India was observed $1.049 \mathrm{~kg} / \mathrm{d} / \mathrm{h}$ that the buffaloes got adequate DCP as per the requirement (Chavda et al., 2016). However, according to Kearl, (1982), it was undersupplied (varied from 300-500 $\mathrm{gm} / \mathrm{d} / \mathrm{h}$ ) as compared to standard requirement
(Table 5). Other studies aimed at evaluating the nutritional status of dairy animals in India based on survey of different districts/regions showed variable trends. Most of them showed undersupply of DCP as compared to standard requirements (Bakshi et al., 2010; Jawale et al., 2007; Singh et al., 2003; Vidya et al.,2013). These findings agreed with our present observation. Daily average TDN supply in the buffaloes in different climatic areas of Bangladesh were observed $5.936 \mathrm{~kg} / \mathrm{d}$ (Table 4) which was $0.350-2.589 \mathrm{~kg} / \mathrm{d}$ deficit as compared to requirement according to Kearl (1982).

Daily average deficit of TDN supply in the buffaloes were $0.353,2.589$ and $2.199 \mathrm{~kg} / \mathrm{d}$ for coastal, river basin and drought areas, respectively (Table 4). Chavda et al. (2016) got surplus amount of average TDN intake (10.17 $\mathrm{kg} / \mathrm{d}$ ) in the buffaloes in Patan district of India as compared to standard requirement. The findings of Chavda et al. (2016) are supported by the observations of Patange et al. (2002) and Singh et al.(2003) indicating a surplus TDN supply against requirement of the buffaloes surveyed. However, deficit supply of TDN in lactating buffaloes was also reported by Chaturvedi et al. (2009) and Singh et al.(2008) in their study. As a part of the traditional feeding system, milking buffaloes were given fixed allowance of concentrate ( 1 to $3 \mathrm{~kg} / \mathrm{head} /$ day) without taking into account their relative daily milk production capacity in Bangladesh. As they provide concentrate to the buffalo not considering the productivity, it causes nutritional deficiency in high productive buffaloes. This situation can be improved by grouping the buffaloes according to milk yield and providing one $\mathrm{kg}$ concentrate for each two liters milk production (Habib et al., 2007). Indian Council of Agricultural Research (ICAR) has been recommended some standard concentrate mixture containing about 20\% CP and $70 \%$ TDN for lactating buffalo based on Indian feed resources. In comparison to Kearl, (1982) the majority of the lactating buffaloes in different climatic areas in Bangladesh were not being adequately fed in terms of energy and proteins. Therefore, animals remain deficient and the milk production was not increased to its potential. The overall supply of DCP and TDN in comparison to their calculated requirements to buffaloes indicated that the farmers of those areas used their traditional practice in feeding their livestock.

The concentration of $\mathrm{CP}$ on DM should be between 11 and 14\% (Rai and Aggarwal,1991) but Verna et al.(1992) and Verna et al.(1994) 


\section{Buffaloes in different climatic zones of Bangladesh}

showed that protein levels in the diet of lactating dairy buffalo varies around 12\% (DM basis). Changes in protein levels of diet can affect the concentration of protein in milk as well as blood urea $(B U)$ concentration. Milk production $(\mathrm{kg} / \mathrm{d})$, milk protein quantity and milk urea (MU) increased with increase of $\mathrm{CP} \%$ in diet (Campanile et al.,1998). Inadequate energy and minerals in the supplement, microbial population in the rumen would not efficiently utilize resulting ammonia and the excess will be absorbed and converted to urea in the liver (Sarwar and Zia-ulHassan, 2001) and will ultimately be excreted in the urine. Javaid (2007) suggested that feeding diets containing rumen degradable protein (RDP) to rumen undegradable protein (RUP) ratio (50RDP:50RUP) increased DMI, milk yield in lactating dairy buffalo. High circulatory levels of urea have been widely advocated to adversely affect reproduction and health of the animals and also contribute to environmental pollution through excretion of large amounts of nitrogen by the animal (Shukat, 2004). Based on the above discussion, energy and DCP should be supplied according to the demand for the climate resilient production system.

\section{Production variables}

Production performances e.g. milk production, lactation length, lactation yield and milk composition of buffaloes are affected by feeding, management, nutrition, disease and in most cases heritability. Climate variables (i.e. air temperature, humidity, wind velocity, solar radiation) also influence the lactation length, lactation yield and buffalo milk production in tropical climate.

Body weight of lactating costal buffaloes was observed significantly $(p=0.000)$ lower $(35 \%)$ than that of the drought (130 kg/h less) and river basin $(138 \mathrm{~kg} / \mathrm{h}$ less) buffaloes. Similarly Lapitan et al. (2008) conducted an experiment in Philippines where crossbred young water buffalo were used and body weighted ranged from 300$389 \mathrm{~kg}$. In the contrary, havier lactating buffaloes, body weight ranged 470-478 kg were used in feeding trail in river basin and coastal area of Bangladesh, Siddiki (2017).

From the study it is comprehensible that the average daily milk yield was significantly higher (1.6-3.1 L/d higher) in drought area than that of the river basin and costal area, respectively. Average milk yield was 2-5 L/d among the three studied areas. This findings similar to Siddiki (2017) and Karim et al.(2013). Siddiki (2017) reported that average daily milk production varied from 1.65 to $3.46 \mathrm{~kg} / \mathrm{d}$ for non-descriptive lactating buffaloes in coastal and river basin area of Bangladesh. Karim et al. (2013) also claimed that that the average milk yield of lactating buffalo under coastal district (Barguna and Pirajpur) of Bangladesh was 3.3-3.4L/day.
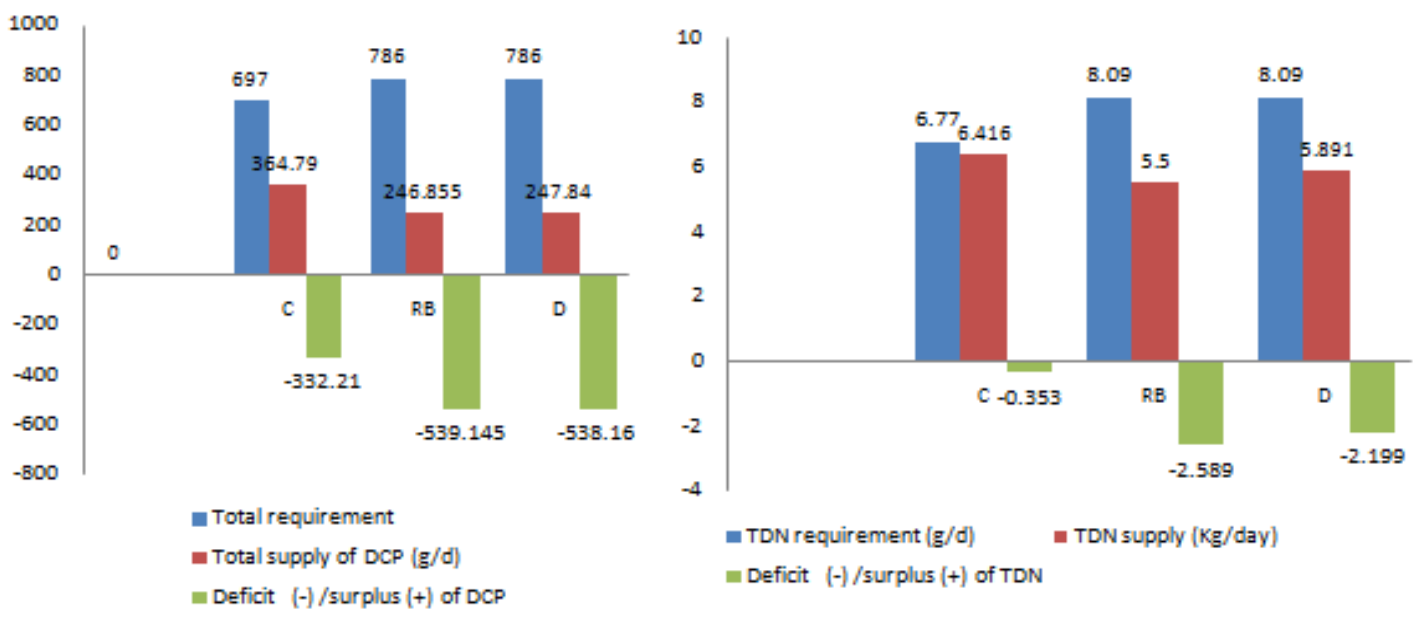

Figure 1: Deficit (-) and surplus (+) of DCP and TDN in lactating buffaloes in selected coastal (C), river basin (RB) and Drought (D) area of Bangladesh. 
Table 6: Body weight, milk production and milk quality of lactating buffaloes in selected coastal (C), river basin (RB) and Drought (D) areas of Bangladesh

\begin{tabular}{|c|c|c|c|c|}
\hline $\begin{array}{l}\text { Production } \\
\text { parameters }\end{array}$ & C & RB & D & $\begin{array}{c}\mathbf{P} \\
\text { value }\end{array}$ \\
\hline Average BW (kg) & $\begin{array}{r}242.0^{\mathrm{b}} \pm 45.1 \\
(182.0-320.0)\end{array}$ & $\begin{array}{r}380.0^{\mathrm{a}} \pm 26.0 \\
(340.0-420.0)\end{array}$ & $\begin{array}{r}372.0^{\mathrm{a}} \pm 45.1 \\
(356.0-381.0)\end{array}$ & 0.000 \\
\hline Average MY (L/d) & $\begin{array}{r}2.2^{\mathrm{c}} \pm 0.6 \\
(1.0-4.0)\end{array}$ & $\begin{array}{l}3.7^{b} \pm 2.0 \\
(1.3-7.3)\end{array}$ & $\begin{array}{l}5.3^{a} \pm 1.3 \\
(3.0-7.0)\end{array}$ & 0.000 \\
\hline Lactation yield(L) & $\begin{array}{r}429.0^{c} \pm 124.3 \\
(196.0-784.0)\end{array}$ & $\begin{array}{r}1085.2^{\mathrm{a}} \pm 568.5 \\
(392.0-2156.0)\end{array}$ & $\begin{array}{r}1007.3^{b} \pm 252.4 \\
(567.0-1512.0)\end{array}$ & 0.000 \\
\hline Lactation Length(d) & $\begin{array}{r}197.4^{\mathrm{b}} \pm 29.1 \\
(150.0-270.0)\end{array}$ & $\begin{array}{r}293.9^{a} \pm 18.2 \\
(240.0-325.0)\end{array}$ & $\begin{array}{r}188.7^{b} \pm 13.1 \\
(170.0-210.0)\end{array}$ & 0.000 \\
\hline Protein (\%) & $\begin{array}{r}3.6^{\mathrm{b}} \pm 0.4 \\
(3.0-4.4)\end{array}$ & $\begin{array}{r}3.7^{\mathrm{b}} \pm 0.3 \\
(3.1-4.1)\end{array}$ & $\begin{array}{l}4.1^{\mathrm{a}} \pm 0.4 \\
(3.7-4.7)\end{array}$ & 0.001 \\
\hline Lactose (\%) & $\begin{array}{r}4.0^{c} \pm 0.3 \\
(3.6-4.8)\end{array}$ & $\begin{array}{l}4.9^{\mathrm{a}} \pm 0.5 \\
(4.3-5.8)\end{array}$ & $\begin{array}{r}4.6^{\mathrm{b}} \pm 0.2 \\
(4.3-5.0)\end{array}$ & 0.000 \\
\hline Fat $(\%)$ & $\begin{array}{r}7.3 \pm 2.7 \\
(4.1-12.0)\end{array}$ & $\begin{array}{r}6.6 \pm 1.5 \\
(5.1-10.3)\end{array}$ & $\begin{array}{r}7.6 \pm 1.1 \\
(6.1-10.0)\end{array}$ & 0.274 \\
\hline $4 \%$ FCM yield $(\mathrm{kg} / \mathrm{d})$ & $\begin{array}{r}3.1^{\mathrm{b}} \pm 1.3 \\
(1.5-5.9)\end{array}$ & $\begin{array}{r}3.6^{\mathrm{b}} \pm 2.1 \\
(1.6-9.0)\end{array}$ & $\begin{array}{r}7.7^{\mathrm{a}} \pm 2.0 \\
(4.0-10.4)\end{array}$ & 0.000 \\
\hline Ash (\%) & $\begin{array}{r}0.6^{\mathrm{b}} \pm 0.1 \\
(0.5-0.8)\end{array}$ & $\begin{array}{r}0.7^{\mathrm{a}} \pm 0.1 \\
(0.6-0.9)\end{array}$ & $\begin{array}{r}0.7^{\mathrm{a}} \pm 0.0 \\
(0.6-0.7)\end{array}$ & 0.000 \\
\hline
\end{tabular}

BW, Body weight; MY, Milk yield; d, day; FCM, Fat corrected milk. Values in the parenthesis represents the data range of the respective mean. $\mathrm{FCM}=0.4 \mathrm{M}+0.15 \mathrm{~F} ; \mathrm{M}$ is the quantity of milk in $\mathrm{Kg}, \mathrm{F}$ is fat content (Kg) of non-standard milk (Gaines, 1928)

The non-descriptive buffalo herd at Bangladesh Livestock Research Institute had an average production of 1.5 - 3.0 L/day (Islam et al.,2014) which also agreed with our findings. As averge daily milk yield was highest in drought area, but significantly higher (1085 L) lactation yield was found in riverbasin area than that of drought (78 $\mathrm{L}$ more) and costal (656L) area due significantly higher (96-105 day more) lactation length in river basin area. It might be happened due to management, environment, and genetic factors. Similar findings were also reported by several authors (Faruque et al., 1990 and Shabede et al., 1993). Karim et al. (2013) found 286 days of lactation period in similar kind of buffaloes under extensive production system in Mathbaria and Pirozpur, which was 290 days in Pathorghata and Barguna. The findings of this study were also more or less similar to the findings of other authors (Faruque et al. ,1990; Faruque and Amin, 1994).

Milk composition attributed for breed, physiology of animal, environment, and management system (Ravikala et al., 2014). Nahar et al. (2014) found different milk composition of buffalo, for different selected areas of Bangladesh. In the present investigation the range of protein, lactose and ash percentage of buffalo milk collected from different climatic zone were 3.64-4.12, 4.03-4.92 and $0.62-0.70$, respectively. The range of protein and lactose percentage were 3.50-4.37 and 4.836.26 respectively, found in different district of Bangladesh (Nahar et al.,2014). The average fat percentage of buffalo milk from Noakhali, Sirajgang, Potuakhali and Bagerhat was 8.16, $7.54,7.18$ and 6.92 respectively (Nahar et al., 2014) which was similar with Khan et al., 


\section{Buffaloes in different climatic zones of Bangladesh}

(2007).Compared to the present results, a lower fat content in non-descriptive buffalo milk (5.8\%) was reported by Islam et al. (2014), on the other hand, Khan et al. (2007); Islam et al.(2018) reported 8.4 and $7.3 \%$ fat in swamp and water buffalo milk from Trishal, Mymensingh. However, the fat content in the non-descriptive buffalo may showed a higher range of variation, for instance $3.4-14.4 \%$ in high altitude area like Kumaon Hills of the central Himalayas (Meena et al., 2007). The present investigation in case of fat $\%$ is agreed with Nahar et al.,2014. The FCM yield varied from 3.08 to $7.77 \mathrm{~kg} /$ day which might be depending for nutrition supply as well as genetic variation. Zhou Caixia (2012) reported that the FCM increased significantly with increased of CP level from 13.6 to $14.4 \%$, but the FCM production decreased from 13.1 to $12.2 \mathrm{~kg} / \mathrm{d}$ with the increased dietary $\mathrm{CP} \%$ from 15.2 to 16.0 in lactating buffaloes in china. Meng et. al. (2016) showed that high crude protein level of diet did not significantly improve the yield of FCM. Hongyu et. al. (2010) also claimed that, above a certain level of dietary protein, can reduce the yield of FCM.

\section{Conclusion}

Buffaloes in the studied areas were mainly reared in traditional management system. Buffalo farmers provide local green grass and rice straw as basal diet with or without very little amount of concentrate supplement consisting of one or few concentrate ingredients separately or in the form of mixture to their buffalo without considering their nutrient requirement (especially energy and protein requirement) based on milk production and composition. As a result the nutritionally deficit buffalo cannot express their full genetic potential in terms of milk production and quality and over supply of nutrient also affects the farm profitability. Therefore, assessment of local natural resources including feeds, fodder, animals and management tools is of greater importance.

\section{Conflict of interest}

The authors have no conflict of interest to declare.

\section{References}

Ahmed TU (2006). Studies on nutritional status of dairy cows of Bangladesh and improvement of their productive and reproductive performance in Baghabarighat area through nutritional manipulation. PhD Thesis, Department of Animal Nutrition, Bangladesh Agricultural University, Mymensingh.
Akbar MA (1992). Nutritional status of livestock in Bangladesh and their future improvement. In; proceeding workshop on livestock development in Bangladesh. Bangladesh Livestock Research Institute (BLRI), Savar, Dhaka: 119-132.

Bakshi MPS, M Wadhwa and JS Hundal (2010). Nutritional status of animals in periurban dairy complexes in Punjab, India. Indian Journal of Animal Science 80:745-749.

Borghese A (2005). Buffalo Population and Strategies in the World. Buffalo Production and Research. FAO regional office for Europe. REU Technical Series:67.

Campanile G, CD Filippo, RD Palo, W Taccone and L Zicarelli (1998). Influence of dietary protein on urea levels in blood and milk of buffalo cows. Livestock Production Science 55:135-143.

Chavda MR and S Parnerkar (2016). Nutritional status of buffaloes in Patan district of North Gujrat. International Journal of Science, Environment and Technology 5(6):4173-4178.

Devendra C and RA Leng (2011). Feed resources for animals in Asia: Issues, strategies for use, intensification and integration for increased productivity. Asian Australasian Journal of Animal Science 24(3): 303-321.

FAO (2010). The state of food and agriculture. Food and Agriculture Organization of the United Nations, Rome. Italy.

FAO (2012). The state of food and agriculture. Food and Agriculture Organization of the United Nations, Rome. Italy.

FAO. (2014). FAOSTAT Database. Food and Agriculture Organization of the United Nations, Rome, Italy. Available at: http://faostat.fao.org/.

Faruque MO and MR Amin (1994). Indigenous buffaloes in coastal areas in Bangladesh. Part I. Distribution pattern and phenotypes. Bangladesh journal of Training and Development 7(1): 83-85.

Faruque MO, MA Hasnath and NU Siddique (1990). Present status of buffaloes and their productivity raised by the small farers of Bangladesh. Asian Australasian Journal of Animal Science 3(4): 284-292.

Feedipedia (2018).Animal feed resources information system, Lathyrus sativus. https://www.feedipedia.org/node/285. Visited on 20/01/2018. 12.20 PM.

Gaines WL (1928). The energy basis of measuring milk yield in dairy cows. Illinois agricultural experiment station bulletin 308. Urbana: University of Illinois.

Habib G, A Hameed and M Kamal (2007). Current feeding management of peri urban dairy buffaloes and scope for improvement. Pakistan Veterinary Journal 27(1): 35-41.

Hamid M, M Siddiky, M Rahman and K Hossain (2017). Scopes and opportunities of buffalo 
farming in Bangladesh: A review. SAARC Journal of Agriculture 14(2): 63-77.

Hongyu L, SJ Miao, YB Cheng and ZY Qian (2010). Effect of dietary protein levels on the cold north Chinese Holstein lactation performance and urea nitrogen in vivo. Chinese Journal of Animal Science 46: 36-39.

Huque KS and MYA Khan (2017). Socio-geographic distribution of livestock and poultry in Bangladesh-a review. Bangladesh Journal of Animal Science 46 (1): 65-81.

Islam MA (2014). Principal components of buffalo and cow milk from Bangladesh: Proteolysis and lipolysis of buffalo, cow and omega-3 enriched milk by ex vivo digestion. PhD Thesis, Norwegian University of life sciences, Aas-1430, Norway.

Islam MA, MK Alam, MN Islam, MAS Khan, D Ekeberg, EO Rukke and GE Vegarud (2014). Principal Milk Components in Buffalo, Holstein Cross, Indigenous Cattle and Red Chittagong Cattle from Bangladesh. Asian-Australas Journal of Animal Science 27(6): 886-897.

Islam MN (2017). Challenge of animal protein for national health security. 4th BSAPER International Conference. 4th International Conference 2017 organized by Bangladesh Society for Animal Production Education and Research (BSAPER), Bangladesh Agricultural University, Mymensingh, 6 May, 2017.

Islam MN and SMR Rahman (2018). Qualitative characteristics and self life of buffalo milk in Bangladesh. IX Asian Buffalo Congress, Central Institute for Research on Buffaloes, Hisar, India.

Islam MR, M Hasanuzzaman, MA Jalil and KS Huque (2002). Identification, screening and nutritive value of forages available throughout Bangladesh. Animal Production Research Division, Bangladesh Livestock Research Institute, Savar, Dhaka 1341, Bangladesh: 153.

Jatinder PS, D Avijit and K Sashi (2018). Developing feeding module for increasing milk production in Murrah buffaloes (Bubalus Bubalis). Buffalo Bulletin 37(1): 45-50.

Javaid A (2007). Effect of varying ruminally degradable to undegradable protein ratio on milk production and reproductive performance of dairy buffaloes (Bubalus bubalis), PhD Thesis, University of Agriculture, Faisalabad, Pakistan.

Jawale MR, VD Kank, MB Patil, SV Chopde, C Jagadale and NR Karambele (2007). Nutritional status of dairy animals from Pune district of Maharastra. Conference on International Tropical Animal Nutrition. National Dairy Research Institute, Karnal, India.

Karim MR, MZ Hossain, MR Islam, MS Parvin and MA Matin (2013). Productivity reproductively and management system of indigenous buffalo (Bubalusbubalis) cows in coastal areas of Pirojpur and Borguna district of Bangladesh. Progressive Agriculture 24 (1 \& 2): 117-122.
Kearl LC (1982). Nutrient requirements of ruminants in developing countries. International Feedstuffs Institutes. Utah Agricultural Experiment Station. Utah State University. Logan Utah.

Khan MAS, MN Islam and MSR Siddiki (2007). Physical and chemical composition of swamp and water buffalo milk: a comparative study. Italian Journal of Animal Science 6(2): 10671070.

Lapitan RM, AND Barrio, O Katsube, T Ban-Tokuda, EA Orden, AY Robles, LC Cruz, $\mathrm{K}$ Yukio and $\mathrm{T}$ Fujihara (2008). Comparison of fattening performance in Brahman grade cattle (Bos indicus) and crossbred water buffalo (Bubalus bubalis) fed on high roughage diet. Animal Science Journal 79: 76-82.

Meena HR, H Ram and T Rasool (2007). Milk constituents in non-descript buffaloes reared at high altitudes in the Kumaon hills of the central Himalayas. Buffalo Bulletin 26: 72-76.

Meng F, C Yuan and Z Yu (2016). Effects of Dietary Protein Level on Milk Production Performance and Serum Biochemical Indicators of Dairy Goat Advances in Dairy Research. Journal of Advance Dairy Research 4:3.

Nader GA and PH Robinson (2008). Effects of maceration of rice straw on voluntary intake and performance of growing beef cattle fed rice straw-based rations. Animal Feed Science and Technology 146: 74 - 86

Nahar TN, MK Alam and S Akhtar (2014). Study the assessment of nutritional composition and bacterial load in buffalo milk in some selected areas of Bangladesh. Proceeding of the Annual Research Review Workshop 2012-13, Bangladesh Livestock Research Institute, Savar, Dhaka 1341.

Nahar TN, MM Rahman and MS Islam (2015). Study on availability, present production, and utilization system of different feeds and fodder in selected regions. Proceeding of the annual research review workshop 2013-2014. Bangladesh Livestock Research Institute, Savar, Dhaka1341.

NRC (2001). Nutrient requirement of domestic animals, No.3, Nutrient requirement dairy cattle. National Research Council, National Academy Press, Washington, D.C

Patange DD, AN Kulkarni, BV Gujar and SD Kalyanrkar (2002). Nutrient availability to milch Marathwadi buffaloes in their home tract. Indian Journal of Animal Nutrition 19: 41-46.

Poondusit T (2001). Comparison of rumen ecology and fattening performance of male dairy, beef cattle and buffalo. MS Thesis, Kasetsart University, Bangkok, Thailand.

Rahman MM, S Akhtar and MM Hossaain (1998). The availability of livestock feeds and feeding practices followed by the farmers of some areas of Mymensingh District. Bangladesh Journal of Animal Science 27: $119-126$. 


\section{Buffaloes in different climatic zones of Bangladesh}

Rahman SMR, MN Islam, HM Rashid, MSR Siddiki and MA Islam (2018). Dairy buffalo production system under semi-intensive condition at the coastal area of Bangladesh. 4th International Exhibition and Seminar on Dairy, Aqua and Pet. Animal Health Companies Association of Bangladesh (AHCAB), BICC, Dhaka, Bangladesh. P.363.

Rahman SMR, NR Sarker, MR Amin, M Kamruzzaman and MR Haque (2017). Identification of naturally available forage species and their feeding effect on dairy cows in different climatic vulnerable areas of Bangladesh. Bangladesh Journal of Animal Science 46 (2): 150-158.

Rai S and SK Aggarwal (1991). Effect of substitution of green fodder with ammoniated straw on nutrient utilization and milk production in Murrah buffaloes. Buffalo Journal 1: 51-61.

Ravikala K, TK Patbandha and PH Vataliya (2014). Nutritional management of dairy animals through milk yield and its component evaluation. Annual Convention of Indian Society of Animal Production and Management, Anand, Gujarat, India. pp. 137-144.

Saadullah M (2012). Buffalo production and constants in Bangladesh. Journal of Animal and Plant Sciences 22 (3): 221-224.

Sarker NR, MA Habib, MR Amin, S Yeasmin, F Tabassum and D Yeasmi (2017). Feeds and fodder dynamics in selected river basins of Bangladesh. Bangladesh Journal of Animal Science 46 (3): 206-214.

Sarwar M and Zia-ul-Hassan (2001). Nutrient Metabolism in Ruminants. University Press, University of Agriculture, Faisalabad, Pakistan.

Shabade NS, DZ Jagtap and ND Behle (1993). Factors affecting production and production efficiency traits of first lactation Murrah buffaloes. Indian Journal of Animal Science 63(11): 1212-1213.

Shukat A (2004). Relationship of blood urea and milk urea nitrogen concentrations at different feeding, milk production levels and milking times in dairy cows with different protein intake. MS Thesis, NWFP Agricultural University, Peshawar, Pakistan.

Siddiki MA (2017). Improvement of production potential of buffaloes supplemented with protein and energy based diets. PhD Thesis. Department of Animal Science, Bangladesh Agricultural University, Mymensingh.

Siddiky MNA (2018). Buffalo for dairying in South Asia: potential, challenges and way forward. 4th International Exhibition and Seminar on Dairy, Aqua and Pet. Animal Health Companies Association of Bangladesh (AHCAB), BICC, Dhaka, Bangladesh. p 324
Siddiquee N, MO Faruque, F Islam, MA Mijan and MA Habib (2010). Morphometric Measurements, Productive and Reproductive Performance of Buffalo In Trishal and Companiganj SubDistricts of Bangladesh. International Journal Bio Research 1(6): 15-21.

Singh CB, PS Pramanik and S Mishra (2003). Availability of nutrients from prevailing feeds and fodders to dairy animals in eastern plain zone of Uttar Pradesh. Indian Veterinary Medicine Journal 27: 53-54.

Singh VK, P Singh, AK Verma, and UR Mehra (2008). On farm assessment of nutritional status of lactating cattle and buffaloes in urban, periurban and rural areas of Middle Gangetic Plains. Livestock Research and Rural Development. 20: 130 .

Tareque AMM (1991). Feeds and Fodder Resources in Bangladesh and Patterns of Utilization. ADS, Second Livestock Project, Dhaka, Bangladesh.

TNAU Agritech Portal (2018). Breeding management of cattle and buffaloes. http://agritech.tnau.ac.in/expert_system/cattle buffalo/Breeding\%20management $\% 20$ of\%20cat tle\%20and\%20buffaloes-2.html. Visited on 19/01/2018. 22.20 PM

Uddin JM (2001). Effect of supplementary feeding on production characteristics of dairy buffaloes. MS Thesis, Department of Animal Nutrition, Bangladesh Agricultural University, Mymensingh.

Verna M, S Bartocci, A Amici and M Agostini (1992). Effect of diets with different energetic concentration on the qualitative and quantitative yield in lactating buffaloes. Symposium on Prospect of Buffalo Production in the Mediterranean and the Middle East. Cairo, Egypt. pp. 258-261.

Verna M, S Bartocci, A Amici and M Agostini (1994). Effetto di diete diverse sulleprestazion produttive di bufale in lattazione. Agric. Ricerca 153: 73- 78

Vidya S, RK Anand and SV Dwivedi (2013). Nutritional status and reproductive performance of dairy cattle and buffaloes in Sonbhadra district of Uttar Pradesh. International Journal of Science and Nature 4: 494-498.

Zhou CX, SJ Wei and XW Liang (2012). Effect of dietary crude protein levels on lactating buffalo milk production and nitrogen metabolism. Journal of Animal Nutrition, 24: 946-952. 